\title{
Aleyrodide
}

J. R. Watson, Gainesville, Fla.

A. W. Morrill, Phoenix, Ariz., will classify for permission to retain specimens if desired.

Coccidoe and Aleyrodidee

W. E. Britton, New Haven, Conn., will elassify in so far as other work will permit. Coccidee

R. H. Pettit, East Lansing, Mich., will classify in so far as other work will permit. Chironomide and Mycetoplitida

O. A. Johannsen, Cornelt University, Ithaca, N. Y, will elassify for the privilege of retaining desiderata.

Itonidida

E. P. Felt, State Education Building, Albany, N. Y., will classify provided the midges are new, from new localities or have been reared and food record is available. Megastigmus

C. R. Crosby, Cornell University, Ithaca, N. Y. Aphidiince and Opizine, sub-families of Braconidee

A. B. Gahan, College Park, Md., will classify on condition that specimens may be retained if desired.

sphecides

H. T. Fernald, Amherst, Mass., will classify provided work be not required immediately on receipt of specimens. Assistant will classify Elidina and graduate students the sub-family A porinae of the family Psammocharida (Pompilida).

A poidea

E. G. Titus, Logan, Utah. For permission to retain types and specimens not present in his collection.

Myron H. Swenk, Lincoln, Neb., will classify members of this group from Nebraska, and any North American member of the following gencra-Colletes, Nomada and Anthidium.

\section{PRELIMINARY LIST OF THE SCALE INSECTS OF SOUTH CAROLINA WITH SOME NOTES ON THE BEHAVIOR OF LECANIUM QUERCIFEX FITCH}

\author{
By Wilson P. GeE
}

No previous systematic attempt seems ever to have been made to collect and identify the scale insects of South Carolina, and except for specimens which have found their way into the collections of workers in other states, there are no records of just what Coccida occur there. During the past year and a half the writer has attempted a partial collection and classification of the scales of this state, and has been able to secure at least the more generally distributed of these. $\mathrm{He}$ wishes to acknowledge here his appreciation of the ready response of Prof. J. G. Sanders, Department of Entomology, University of Wisconsin, to the request for the check identification of all of the softscale insects in this list, and to Mr. E. R. Sasscer, Bureau of Entomology, Washington, D. C., for a similar service in regard to the Diaspine scales. 
The following is a list of the scale insects with their host plants.

1* Chrysomphalus aonidum, Linn. on Palm.

2* Chrysomphalus dictyospermi Morg. on Sabal Palm.

3 Chrysomphalus tenebricosus Comst. on Acer sp.

$4^{*}$ Aspidiolus hedere Vall, on Cycas revoluta.

5 Aspidiolus forbesi Johns on Peach.

6 Aspidiolus perniciosus Comst, on Peach, Plum, Apple, Pear, Rose, and Cherry.

7 Lepidosaphes beckii Newm. on Fig.

8 Lepidosaphes ulmi Linn. on Pyrus malus.

9 Chionaspis furfura Fitch on Pyrus malus.

10 Chionaspis euonymi Comst. on Euonymus japonicus.

11* Parlatoria pergandei var. close to camellice on Euonymus japonicus.

12* Parlatoria pergandei Comst. on Cilrus lemonoe.

13 Fiorina thea Green on Euonymus japonicus.

14 Lecaniodiaspis tessellata Ckll. on Persimmon.

15 Toumeyella liriodendri Gmel, on Liriodendron tulipifera.

16 Saissetia hemisphaerica Targ. on Persea and Cycas revolula.

17 Pulvinaria vilis Linn. on Acer sp.

18 Pulvinaria acericola Walsh and Riley on Acer sp.

19 Pulvinaria camellicola (?) on Cornus florida.

20 Lecanium corni Bouche on Elm.

21 Lecanium nigrofasciatum Pergande on Plum.

22 Lecanium quercifex Fitch on Quercus aquatica.

23 Aulacaspis rosa Bouche on Rose.

24* Coccus hesperidum on Laurel and Cerimon.

25* Pseudococcus cilri on Cilrus aurantium.

26 Pseudophillipia qudintancei Ckll. on Pine.

* Greenhouse species.

General Behavior of Young of Lecanium quercifex Fitch. Eggs of this species were hatching May 15, in such abundance as to afford ample material for the study of some features of its behavior. While not exhaustive in character, many of these results are new and of considerable interest in the explanation of certain activities of not alone this species of scale insects, but also nlany related ones.

Phototaxis. To light of a 16 candle power intensity, the young. insects showed a very marked positive reaction, orientation being very decidedly parallel to the direction of the rays of light. A very few specimens seemed entirely indifferent to the effect of the light rays, but taken as a whole, the reaction reminds one very much of the effect that the electric current has on Paramecium as described by Jennings. ${ }^{1}$ Almost as soon as the light is placed at the other end of the dish, the direction of the movement of the scale insect is reversed and it again moves in the direction of the source of light. The scales of this form occur towards the outer portions of the twigs on the newer wood, and the light reactions of the insect are no doubt an important factor

1 Jennings, H. S. Behavior of the Lower Organisms. New York, 1906. 
in determining this, since the stronger light is to be found towards the tips of the branches.

Geotaxis. When placed on a thin cork board, in a vertical position, the young scale insects began climbing upward against the direction of gravity. This did not continue in all cases until the form had reached the top of the board, but many of the specimens seemed to stop when they reached a height of six or eight inches, though several continued to the top of the board, twelve inches in height. This method of reaction, crawling upward, or negative geotaxis, affords us another factor in the assistance of the light in aiding the young scale insects to reach the newer portions of the growth of the branch, since this part usually projects upward.

Chemotaxis. A very small amount of strong hydrochloric acid, nitric acid, and 95 per cent alcohol were placed in the midst of a large number of young scales on a glass slide, and their movements observed under a binocular. To each of these substances all of the young scales showed a very marked negatively chemotactic response. It would be interesting to test out the effect of a weak tannic acid solution in this relation, and also an extract of the juices of the twigs of the oak, where we would expect a positive reaction; but though this was the intention of the writer, the matter was overlooked until all of the young scales had become old enough to have fixed themselves in their places on the tree.

Thigmotaxis. The young scale insects show very strongly positive thigmotactic propensities. A young nymph which had become turned on its dorsal surface was observed to juggle an unhatched egg, much as a clown would a ball, moving it about with its legs from nine o'clock one morning until five o'clock that afternoon. Observations were discontinued at that time for the day; but the next morning, the performance was still in progress, and continued until about two o'clock that afternoon. At that time the young scale emerged from the egg and it was only with difficulty that the newly emerged individual could escape from the grasp of its young foster-parent. All of this misspent energy came from the attempt of the form to " right " itself, and having caught hold of the egg in its efforts to do this, it lacked sufficient organization of its nervous system to profit from an experience of this kind and continued its futile efforts in this direction until the hatching of the egg relieved it of the object of its misdirected energies. When placed upon their dorsal surfaces they grasp very quickly and cling tightly to such objects held out to them as the fibres of a camel's hair brush, small straws, etc. This positive thigmotaxis is, of course, highly adaptive in nature, and serves to keep the animal in contact with the twig on which it has hatched and will continue to spend its further existence. 